\title{
Coös Youth with Mentors More Likely to Perceive Future Success
}

Kent Scovill and Corinna Jenkins Tucker

I ncreasing national evidence highlights the important association between having a mentor and youths' academic success and well-being. Specifically, youths' mentor relationships often lead to gains in social and emotional development, which are directly reflected in improved academic behaviors and attitudes. ${ }^{1}$ Youth who have mentors are more confident in their abilities and focused on their futures. ${ }^{2}$ Likewise, youth with mentoring relationships have higher levels of self esteem, life satisfaction, ${ }^{3}$ and psychological well-being ${ }^{4}$ than youth with no identified mentor. This fact sheet explores whether Coös youths' mentor experiences and their academic attitudes and well-being are linked. To do so, we analyze data from the Coös Youth Study collected in 2008, focusing on seventh and eleventh grade students from all public schools in Coös County, New Hampshire.

\section{Mentorship and Youths' Perceptions of College Completion}

Mentor relationships were assessed by asking Coös youth, "Is there an adult other than your parent or guardian with whom you share a special bond?" Out of 635 students, 60 percent reported a mentor relationship. When asked about the likelihood of graduating college, youth with a mentor were more positive about achieving this aspiration (82 percent) than Coös youth without a mentor (72 percent) (see Figure 1$).^{5}$

\section{KEY FINDINGS}

Of the Coös youth surveyed, 82 percent with a

80\% mentor relationship reported believing that they

$82 \%$ were likely to graduate college, compared to 72 percent of those without a mentor.

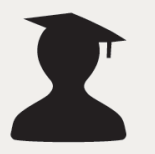

Seventy-eight percent of youth with a mentor agreed that they go to school because they enjoy academic subjects, while 71 percent of youth without a mentor agreed.

Sixty-three percent of Coös youth with a

$63 \%$ mentor agreed that they could do anything they set their minds to, while 53 percent of youth without a mentor agreed.

\section{Mentor Relationships and Youths' Academic Enjoyment}

Seventy-eight percent of Coös youth with a mentor agreed with the statement: "I come to school because I enjoy academic subjects," while only 71 percent of youth who did not report a mentor agreed (see Figure 1$){ }^{6}$

Huddleston Hall, 73 Main Street, Durham, NH 03824

(603) 862-2821 • www.carseyinstitute.unh.edu

$\triangle$ UNIVERSITY

CARSEY

BuILding KNOWLEDge FOR FAmilies And Communities
This work was supported by the The Neil and Louise

Tillotson Fund of the New Hampshire Charitable Foundation. 


\section{FIGURE 1. MENTOR RELATIONSHIPS AND WELL-BEING}

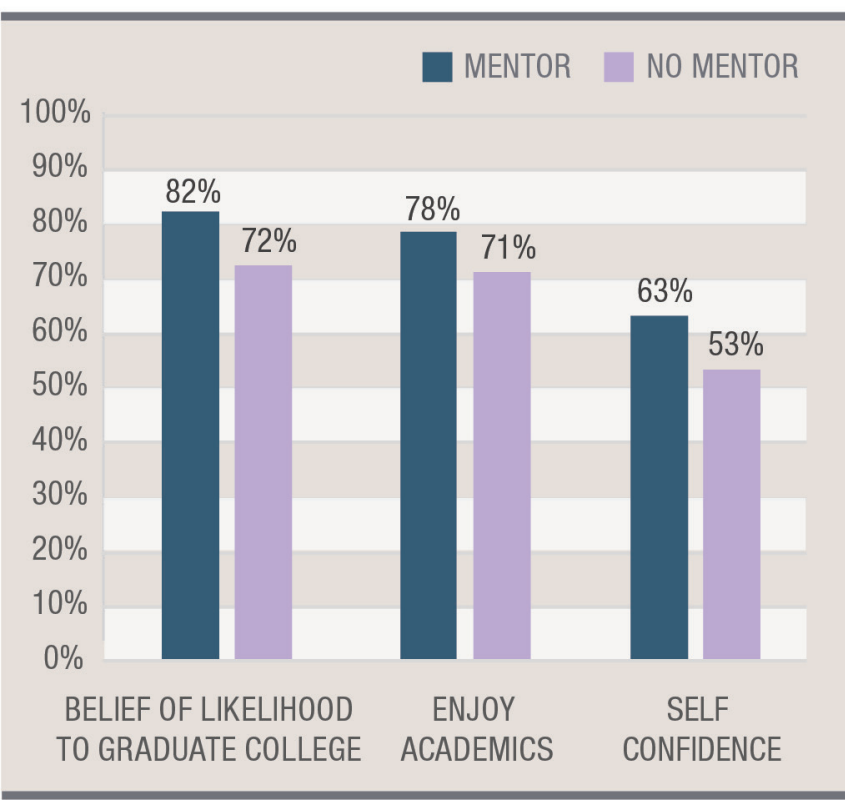

\section{Mentor Relationships and Youths' Self-Confidence}

When Coös youth were asked to agree or disagree with the following statement, "I can do just about anything I put my mind to," those youth with a mentor were more likely to agree (63 percent) than were youth without a mentor (53 percent) (see Figure 1). ${ }^{7}$

\section{Conclusion}

Consistently, national research has shown the positive associations between mentoring and youths' academic attitudes and well-being. ${ }^{8}$ In this fact sheet, we showed that Coös youths' mentor relationships also were significantly associated with these facets of youth functioning. While we can't say definitively that there is a causal relationship between mentorship and youths' academic attitudes and well-being, these findings show there is an association. Given the benefits of mentor relationships for youth, increased efforts should be made in Coös County to promote and increase the longevity of mentor relationships either informally or through established mentoring programs like Big Brother/Big Sister.

\section{Endnotes}

1. J. A. Durlak et al., "The impact of enhancing students' social and emotional learning: A meta-analysis of school-based universal interventions," Child Development, vol. 82 (2011): 405-432.

2. J. E. Rhodes et al., "A model for the influence of mentoring relationships on youth development," Journal of Community Psychology, vol. 34 (2006): 691-707.

3. D. L. DuBois and N. Silverthorn, "Natural mentoring relationships and adolescent health: Evidence from a national study," American Journal of Public Health, vol. 95 (2005): 518-524.

4. M. N. Hurd and M. R. Sellers, "Black adolescents' relationships with natural mentors: associations with academic engagement via social and emotional development," Cultural Diversity and Ethnic Minority Psychology, vol. 19 (2013): 76-85.

5. A chi-squared tested showed a significant difference in Coös youths with versus without a mentor in their beliefs in their likelihood to graduate college.

6. A chi-squared test showed a significant difference in Coös youths with versus without a mentor in their reports of going to school because they enjoy academic subjects.

7. A chi-squared test showed a significant difference in Coös youths with versus without a mentor in their reports of being able to do anything they set their minds to.

8. J. E. Rhodes et al., "A model for the influence of mentoring relationships."

\section{About the Authors}

Kent Scovill is a master of science candidate in family studies at the University of New Hampshire (kcn2@ unh.edu).

Corinna Jenkins Tucker, PhD, CFLE, is a Carsey Institute faculty fellow and an associate professor in family studies at the University of New Hampshire (cjtucker@unh.edu).

\section{Acknowledgements}

This research is supported by the Neil and Louise Tillotson Fund of the New Hampshire Charitable Foundation, the Carsey Institute, and the National Science Foundation (\#155797). The Coös Youth Study Team thanks the students participating in this research project and the superintendents, principals, guidance counselors, teachers, and administrators who helped the team collect these data. Special thanks to fellow members of the Coös Youth Study research team, including Cesar Rebellon, Erin Hiley Sharp, and Karen Van Gundy and, project director, Eleanor Jaffee. Thank you to Amy Sterndale and Laurel Lloyd at the Carsey Institute for their editorial assistance. 